\title{
Mass mortality in seals caused by a newly discovered virus-like morbillivirus
}

\author{
A.D.M.E. Osterhaus ${ }^{1}$, J. Groen ${ }^{1}$, H.E.M. Spijkers ${ }^{1}$, H.W.J. Broeders ${ }^{1}$, F.G.C.M. \\ UytdeHaag $^{1}$, P. de Vries ${ }^{1}$, J.S. Teppema ${ }^{1}$, I.K.G. Visser ${ }^{2}$, M.W.G. van de Bildt ${ }^{2}$ \\ and E.J. Vedder ${ }^{2}$ \\ ${ }^{1}$ National Institute of Public Health and Environmental Protection, P.O. Box 1, 3720 BA Bilthoven \\ (The Netherlands) \\ ${ }^{2}$ Seal Rehabilitation and Research Center, Hoofdstraat 94A, 9968 AG Pieterburen (The Netherlands)
}

\section{ABSTRACT}

Osterhaus, A.D.M.E., Groen, J., Spijkers, H.E.M., Broeders, H.W.J., UytdeHaag, F.G.C.M., De Vries, P., Teppema, J.S., Visser, I.K.G., Van de Bildt, M.W.G. and Vedder, E.J., 1990. Mass mortality in seals caused by a newly discovered morbillivirus. Vet. Microbiol., 23: 343-350.

During a recent disease outbreak among harbour seals (Phoca vitulina) in the North and Baltic seas, more than 17000 animals have died. The clinical symptoms and pathological findings were similar to those of distemper in dogs. Based on a seroepizootiological study, using a canine distemper virus (CDV) neutralization assay, it was shown that CDV or a closely related morbillivirus (phocid distemper virus-PDV) was the primary cause of the disease. The virus was isolated in cell culture from the organs of dead seals and characterized as a morbillivirus by serology (immunofluorescence neutralization and enzyme-linked immunosorbent assays) and by negative contrast electron microscopy. Experimental infection of SPF dogs resulted in the development of mild clinical signs of distemper and CDV-neutralizing antibodies. The disease was reproduced in seals by experimental inoculation of organ material from animals that had died during the outbreak. However, seals that had been vaccinated with experimental inactivated CDV vaccines were protected against this challenge. This fulfilled the last of Koch's postulates, confirming that the morbillivirus isolated from the seal organs, was the primary cause of the disease outbreak. The recent demonstration of the presence of a similar virus in Lake Baikal seals (Phoca sibirica), which infected these Siberian seals 1 year before the northwestern European seals were infected, raises new questions about the origin of this infectious disease in pinnipeds.

\section{INTRODUCTION}

From April 1988 onward, an outbreak of a serious, apparently infectious, disease among harbour seals (Phoca vitulina) spread from the Kattegat area in Denmark to the North sea, the Wadden sea and the Baltic sea. The mortality rate was very high and exceeded $80 \%$ in certain areas. By the end of 1988 
more than 17000 harbour seals had died. Clinical signs and pathological lesions indicated that, apart from general depression and fever, the animals suffered from inflammatory processes in the respiratory and the gastrointestinal tracts, the central nervous system and the parenchymal organs; cutaneous lesions were also found frequently. At the beginning of the outbreak when the pups had not yet been born, large scale abortions were the first signs noticed in the Kattegat area. Due to an apparent malfunction of their immune system, probably caused by the primary causative agent of the disease outbreak, a variety of secondary viral, bacterial and parasitic infections were encountered. For this reason the disease presented itself in different forms at different locations and times during the outbreak and therefore it was initially even discussed if one single disease entity should be held responsible for the massive seal deaths (Osterhaus, 1988). During different expert meetings in 1988 , held in the different countries involved, at which experts from different disciplines and countries were present, possible explanations for the deaths included not only an infectious agent, but also the effects of overpopulation and environmental pollution. Special attention was given to the possibility of a triggering role for certain pollutants and of the drastically increased concentrations of certain algae in the same area during the same period. No clear indications for the involvement of these factors were found.

\section{INITIAL VIROLOGICAL INVESTIGATIONS}

When we applied virus isolation procedures, using primary seal kidney cell cultures, to the lungs and other organs of dead animals from the Danish, German and Dutch waters, a herpesvirus was initially isolated from approximately one out of four animals. Four years before, we also isolated a herpesvirus, Phocid herpesvirus-1, during an outbreak of a disease with high mortality in baby seals, nursed in the Seal Rehabilitation and Research Center in Pieterburen (The Netherlands) (Osterhaus et al., 1985). This virus was then characterized as a novel member of the Alphaherpesvirinae subfamily and shown to be the causative agent of the disease during that outbreak. Subsequently it was shown that virus neutralizing antibodies were present in many pinniped species in different areas indicating that this, or a closely related herpesvirus, was widespread (Osterhaus et al., 1987). Apart from the herpesvirus isolated during the recent outbreak, which seemed similar to Phocid herpesvirus-1, a second virus was also isolated from the majority of the lungs of dead seals. This virus was tentatively classified as a member of the Picornaviridae family. However, serological investigations among seals that had suffered the disease, and animals that had not been in contact with diseased or infected animals, indicated clearly that neither of these two viruses could have been the primary cause of the disease outbreak. This was further supported by the results of vaccination studies carried out in the Seal 
Rehabilitation and Research Center in Pieterburen, which showed that seals which had developed virus neutralizing antibodies against either of the viruses after having been vaccinated with candidate vaccines were not protected against fatal disease. These data suggested that these two infections, rather than being the primary cause of the disease outbreaks, were opportunistic infections occurring in animals suffering from another infection.

\section{DISCOVERY OF THE INVOLVEMENT OF MORBILLIVIRUS}

Serological studies were then extended to other viruses of carnivores, known to cause similar disease signs in their respective hosts. First we looked at the prevalence of antibodies to canine parvovirus, which did not result in any differences between affected and non-affected animals. Subsequently we screened a large panel of seal sera from The Netherlands, Denmark, Germany, Sweden and the United Kingdom, partly collected before and partly after the start of the outbreak, in a virus neutralization test for antibodies to canine distemper virus (CDV). None of the sera collected before the beginning of the outbreak had CDV neutralizing antibody, whereas the majority of the serum samples collected from affected animals in the respective areas contained CDV neutralizing antibodies (Osterhaus and Vedder, 1988; Osterhaus et al., 1988b; Osterhaus et al., 1988d). Paired serum samples collected from 23 harbour seals and one grey seal (Halichoerus gryphus) in the Seal Research and Rehabilitation Center in Pieterburen, before and after the development of clinical signs, were also tested in the CDV neutralization test. All, except one harbour seal, had developed CDV neutralizing antibody titres ( $\geq 10$ ) during or after the disease. That the antibodies found were not directed against measles virus, a closely related morbillivirus, was shown in a measles virus-specific haemagglutination inhibition test, in which CDV-neutralizing seal sera were negative. These data clearly showed that an infection with CDV or a closely related morbillivirus occurred in the respective seal populations after April 1988 and coincided with the occurrence of the disease. Furthermore, the clinical signs observed during the outbreak were similar to those of canine distemper, which is also frequently accompanied by secondary viral and bacterial infections (Appel, 1987). On the basis of the serological and clinical data, it was concluded that the primary cause of the disease outbreak among the seals was CDV or a closely related morbillivirus (Osterhaus et al., 1988a).

\section{ISOLATION OF THE VIRUS}

The initial failure to isolate the virus from the organs of affected animals may be explained by the fact that the isolation techniques used did not favour the isolation of morbilliviruses (Appel, 1987). Using in vitro isolation procedures, we subsequently attempted to isolate the virus either directly or after 
a passage in SPF dogs (Osterhaus et al., 1988a; Osterhaus et al., 1988c). We isolated the virus directly by inoculating monolayer cultures of canine kidney cells (MDCK-cell line) with a suspension of spleen and intestinal lymph node cells. Subsequently the presence of morbillivirus nucleoprotein was shown in these cells in an immunofluorescence test with a monoclonal antibody. The specificity of this immunofluorescence was confirmed by blocking with a hyperimmune anti-CDV SPF dog serum, but not with a pre-immune serum of the same dog.

The virus was also isolated by inoculating two SPF Beagle dogs (from a closed caesarian-derived breeding colony) by the oculo-nasal and peritoneal routes with a pooled suspension of spleen, lung and intestinal lymph node cells from three harbour seals, which had died from the disease in the Wadden sea area, and a subsequent co-cultivation of their peripheral blood mononuclear cells (PBMC) with SPF dog lung macrophages. Both dogs developed mild clinical signs suggestive of CDV infection during a 12-day observation period, including respiratory symptoms with purulent nasal discharge. The body temperature rose above $39^{\circ} \mathrm{C}$ in one of the dogs and in both dogs a lymphopenia was demonstrated. The presence of a morbillivirus was demonstrated in the lung macrophages after co-cultivation, by showing the for-

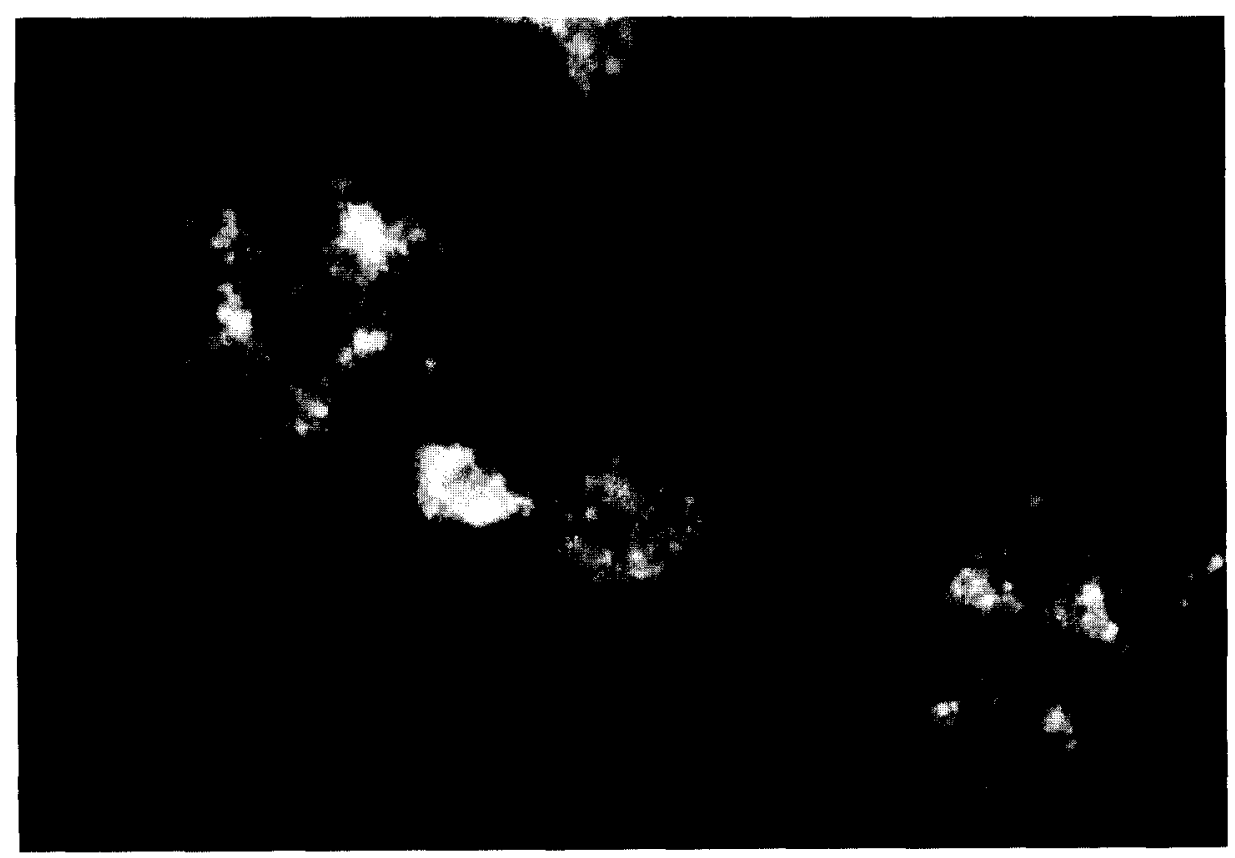

Fig. 1. Indirect immunofluorescence with CDV-specific antiserum, of syncytia in a SPF dog macrophage culture, co-cultivated with peripheral blood mononuclear cells of SPF dogs infected with seal organ suspension. 


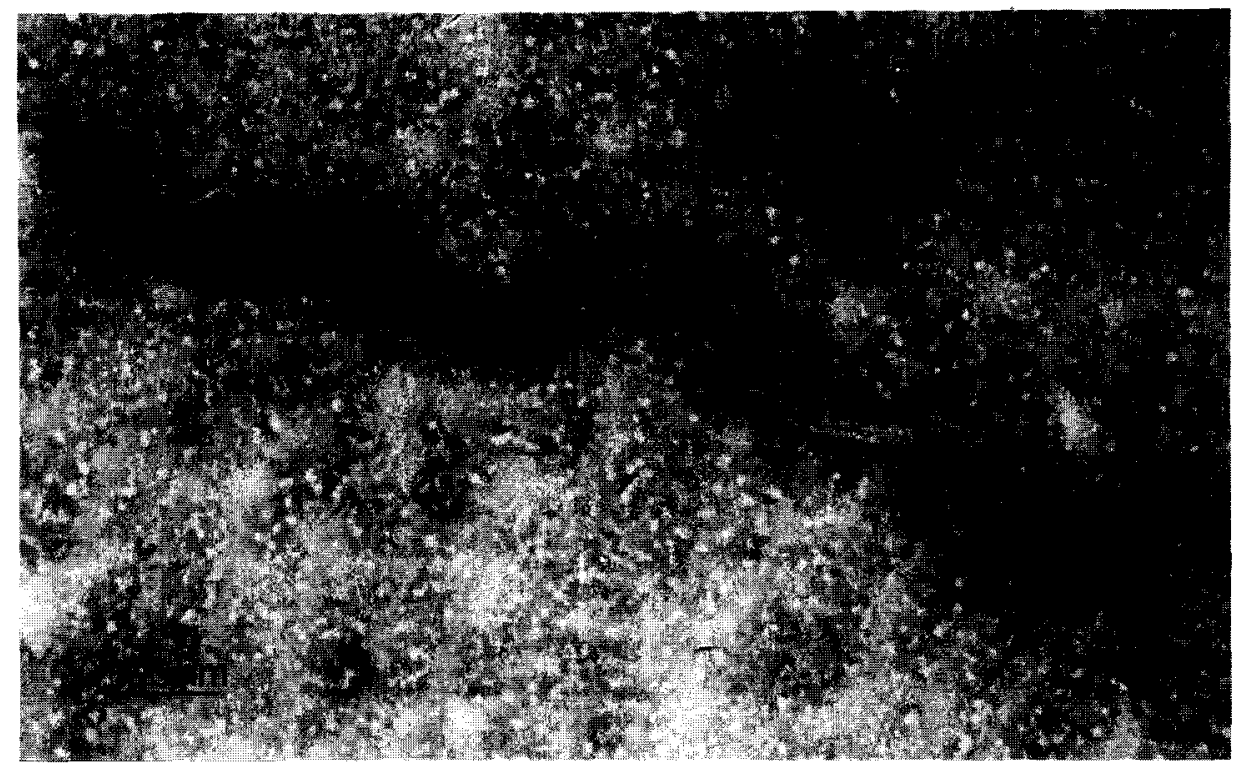

Fig. 2. Negative contrast electron microscopy (PTA) of paramyxovirus nucleocapsid, observed in lysate of SPF dog macrophage culture, co-cultivated with peripheral blood mononuclear cells of SPF dogs infected with seal organ suspension.

mation of syncytia and the demonstration of morbillivirus antigen in these syncytia by indirect immunofluorescence (Fig. 1). Furthermore paramyxovirus nucleocapsids were shown in lysates of the infected macrophages by negative contrast electron microscopy (Fig. 2). The isolated virus could be passaged in SPF dog lung macrophages, and also in African green monkey kidney cells (Vero cell line). Both dogs also developed CDV-neutralizing antibodies within 10 days, with titres of 64 and 128 respectively. These data clearly confirmed that CDV or a closely related morbillivirus had been present in the suspension of pooled seal cells, used for the inoculation of the dogs. During the observation period none of the dogs developed antibodies to Phocid herpesvirus- 1 or the picorna-like virus as judged by testing their plasma samples in virus neutralization assays, indicating that these viruses were not responsible for the clinical signs in the dogs.

\section{EPIDEMIOLOGICAL INVESTIGATIONS}

To further investigate where and when the morbillivirus infection had been introduced into seal populations, the serological studies were extended to a large panel of serum samples from harbour seals collected between 1984 and 1988 , before the outbreak had started from the North sea area, and to samples from seven other pinniped species in the West and East Behring seas and the Antarctic, all collected in the same period. All these samples proved to be negative in the CDV neutralization assay (titre $<10$ ). As the humoral immune response after natural morbillivirus infection persists for several years 
and perhaps even for life as for example in dogs after CDV infection and assuming that this holds also true for the morbillivirus infection of pinnipeds, it was concluded that the morbillivirus involved in this outbreak had not commonly infected pinnipeds (Osterhaus et al., 1988a). The first confirmation of our findings came from a research group in Belfast (Northern Ireland), which showed the presence of typical inclusion bodies and demonstrated morbillivirus-specific immunofluorescence in organs of affected harbour seals. They also isolated the virus by culture of cells from the kidney of a seal that had encephalitis and ophthalmitis (Kennedy et al., 1988). Further evidence that a morbillivirus was the primary cause of the disease outbreak came from workers of The Animal Virus Research Institute in Pirbright (Great Britain), who showed by nucleic acid hybridization studies with CDV and rinderpest virus (RPV)-specific probes that the virus involved was a morbillivirus similar to both these viruses, but distinct from CDV (Mahy et al., 1988). This was supported by studies with monoclonal antibodies raised against CDV and RPV, carried out by the Belfast group (Cosby et al., 1988).

\section{EVALUATION OF EXPERIMENTAL VACCINES}

As further evidence that the primary cause of the epizootic of distemper was the morbillivirus, now named phocid distemper virus (PDV), we evaluated the efficiency of two inactivated CDV vaccines, both shown previously to be effective in dogs (Osterhaus et al., 1989; Dr. M. Westraete, Duphar BV, Weesp, The Netherlands, personal communication ). If seals could indeed be protected by vaccination with a CDV vaccine, it would not only confirm the close relatedness between PDV and CDV, but it would also provide final proof for this morbillivirus as the primary cause of the recent epizootic in seals. The study was limited to eight adult harbour seals for ethical and practical reasons. They belonged to a breeding group, kept in isolation on the Dutch island of Texel, in which no signs of phocid distemper had been observed in the past. All the animals were seronegative for CDV. Two animals were vaccinated with a candidate iscom CDV vaccine prepared in collaboration with Coopers Animal Health Ltd. (Berkhamsted, Great Britain) as previously described (Cosby et al., 1988); the other four were vaccinated with a candidate inactivated whole virus CDV vaccine, kindly provided by Duphar BV (Weesp, The Netherlands). The two other animals were sham-vaccinated with an antigenfree preparation. All eight animals were vaccinated thrice intramuscularly. The six CDV-vaccinated animals developed CDV - neutralizing antibody titers ranging from 300 to 1000 . Ten days after the last vaccination, the eight animals were transferred to a closed swimming pool and challenged intraperitoneally and oculo-nasally, with the organ suspension material that had produced disease in the SPF dogs. The two sham-vaccinated seals developed acute respiratory disease and mucopurulent nasal discharge about 2 weeks after challenge and died on day 14 and 18 respectively. Viral antigen was detected 
in the spleens and/or lungs of both these animals in an ELISA, using antiCDV monoclonal antibodies. The six CDV-vaccinated seals did not develop any clinical signs upon challenge. Although the number of animals studied was small, the data support the conclusion that seals can be protected from phocid distemper by vaccination with certain inactivated CDV vaccines. Since the disease was only produced in unvaccinated seals, the last of Koch's postulates was also fulfilled, confirming that infection with the seal morbillivirus is the primary cause of the epizootic (Osterhaus, 1989; Osterhaus et al., 1989a).

\section{THE ORIGIN OF THE INFECTION}

The origin of PDV and the source of infection of the European seals with this virus is not known at present. In a recent serological study among seals in Greenland, it was shown that CDV-neutralizing antibodies were present in these seals before the beginning of the outbreak in the seals of north-western Europe (Have et al., 1989). Similarly CDV-neutralizing antibodies were demonstrated in the sera of Lake Baikal seals (Phoca sibirica) in Siberia, during and after an outbreak of a distemper-like disease, in which many of these animals died (Grachev et al., 1989; Osterhaus et al., 1989b). This outbreak occurred in the year before the outbreak in north-western Europe took place. In nucleic acid hybridization studies carried out at the Limnological Institute in Irkutsk (USSR), morbillivirus-specific RNA could be demonstrated in the organs of seals that had died during that outbreak (Grachev et al., 1989). Similarly, we were able to demonstrate morbillivirus-specific RNA in organ material from dead Lake Baikal seals in collaboration with Dr. T. Barrett (The Animal Virus Research Institute, Pirbright, unpublish' 'observation). We also isolated a CDV-like morbillivirus in dog macrophages after passaging the virus from seal organ material through SPF Beagle dogs, by co-cultivating their peripheral blood mononuclear cells with the macrophages, as we did in the virus isolation studies from European seals. Viral antigen and nucleic acid was demonstrated in these cultures essentially as described before (Osterhaus et al., 1988a ). Also these SPF Beagle dogs developed mild clinical symptoms resembling the mild CDV infections observed with a virulent strain of CDV in SPF dogs (Cosby et al., 1988). These observations clearly show that a similar PDV-like infection has occurred in the Lake Baikal seals which live completely isolated from other pinniped species before the outbreak had taken place in the North and Baltic seas. Further biological and molecular-biological characterization of the viruses isolated during both outbreaks will be needed to conclude whether an epizootiological link existed between them. If so, the virus may have spread by infection of terrestrial carnivores or may have been transmitted by migrating birds. In this context it is interesting to note that in both outbreaks, spontaneous transmission of the disease to domestic dogs were claimed to occur (unpublished observations). 
Note added in proof. We now have evidence that no epizootiological link exists between the outbreaks in Europe and Siberia, and we have concluded that PDV-1 should be considered a newly recognized member of the genus Morbillivirus, whereas PDV-2 has proved to be quite similar if not identical to CDV (Visser et al., 1990).

\section{REFERENCES}

Appel, M.J.G., 1987. Canine distemper virus. In: M.C. Horzinek (Editor), Virus Infection of Vertebrates. Volume 1: Virus Infection of Carnivores. Elsevier Scientific Publishing Company, Amsterdam, pp. 133-161.

Cosby, S.L., McQuaid, S., Duffy, N., Lyons, C., Rima, B.K., Allan, G.M., McCullough, S.J., Kennedy, S., Smyth, J.A., McNeilly, F., Craig, C. and Örvell, C., 1988. Characterization of a seal morbillivirus. Nature, 336: 115-116.

Grachev, M.A., Kumarev, V.P., Mamaev, L.V., Zorin, V.L., Baranova, L.V., Denikina, N.N., Delikov, S.I., Petrov, E.A., Kolesnik, V.S., Kolesnik, R.S., Dorofeev, V.M., Beim, A.M., Kudelin, V.N., Nagieva, F.G. and Sidorov, V.N., 1989. Distemper virus in Baikal seals. Nature, 338: 209.

Have, P., Dietz, R. and Heide-Jørgensen, M.P., 1989. Survey of antibodies against seal distemper virus in seals in Greenland. Abstract International Workshop on Current Research in Seal Disease, 20-22 February, Hannover.

Kennedy, S., Smyth, J.A., McCullough, S.J., Allan, G.M., McNeilly, F. and McQuaid, S., 1988. Confirmation of cause of recent seal deaths. Nature, 335: 404.

Mahy, B.W.J., Barrett, T., Evans, S., Anderson, E.C. and Bostock, C.J., 1988. Characterization of a seal morbillivirus. Nature, 336: 115 .

Osterhaus, A.D.M.E., 1988. Seal death. Nature, 334: 301-302.

Osterhaus, A.D.M.E., 1989. Mass mortality in seals caused by a CDV-like morbillivirus. Abstract International Workshop on Current Research in Seal Disease, 20-22 February, Hannover.

Osterhaus, A.D.M.E., Yang, H., Spijkers, H.E.M., Groen, J., Teppema, J.S. and Van Steenis, G., 1985. The isolation and partial characterization of a highly pathogenic herpesvirus from the harbor seal (Phoca Vitulina). Arch. Virol., 86: 239-251.

Osterhaus, A.D.M.E., Vedder, L., Zarnke, R. and Spijkers, I., 1987. Prevalence of virusneutralizing antibodies to seal herpesvirus (Phocid Herpesvirus 1) in different pinniped species. Abstract 7th Biennial Conference on the Biology of Marine Mammals, 5-9 December 1987, Miami, FL.

Osterhaus, A.D.M.E. and Vedder, E.J., 1988. Identification of virus causing recent seal deaths. Nature, 335: 20.

Osterhaus, A., Groen, J., De Vries, P., UytdeHaag, F., Klingeborn, B. and Zarnke, R., 1988a. Canine distemper virus in seals. Nature, 335: 403-404.

Osterhaus, A., Spijkers, I., Broeders, H., Vedder, E., 1988b. Een uitbraak van 'hondeziekte' bij zeehonden (1) Tijdschr. Diergeneesk., 113: 1011-1012.

Osterhaus, A., Broeders, H., Spijkers, I., Groen, J., Vedder, E., 1988c. Een uitbraak van 'hondeziekte' bij zeehonden (2). Tijdschr. Diergeneesk., 113: 1061-1062.

Osterhaus, A.D.M.E., Vedder, L., Moutou, F., Van Bressem, M.F., Pastoret, P.P., 1988d. La maladie des phoques en Europe. J. Ann. Méd. Vét., 132: 611-621.

Osterhaus, A.D.M.E., UytdeHaag, F.G.C.M., Visser, I.K.G., Vedder, E.J., Reijnders, P.J.M.. Kuiper, J. and Brugge, H.N., 1989a. Seal vaccination success. Nature, 337: 21.

Osterhaus, A.D.M.E., Groen, J., UytdeHaag, F.G.C.M., Visser, I.K.G., Van de Bildt, M.W.G. and Bergman, A., 1989b. Distemper virus in Baikal seals. Nature, 338: 209-210.

Visser, I.K.G., Kumarev, V.P., Örvell, C., De Vries, P., Broeders, H.W.J., Van de Bildt, M.W.G. Groen, J., Teppema, J.S., Burger, M.C., UytdeHaag, F.G.C.M. and Osterhaus, A.D.M.E. 1990. Comparison of two morbilliviruses isolated from seals during outbreaks of distemper in North West Europe and Siberia. Arch. Virol. (in press). 